\title{
Management of Alternaria Blight Disease of Mustard through Nutrients and Fungicides
}

\author{
Sumitra*, S. Meena, S. Choudhary, P. Yadav, S. Godika and R. P. Ghasolia \\ Department of Plant Pathology, SKN College of Agriculture, \\ Jobner (Jaipur, Rajasthan), India \\ *Corresponding author
}

A B S T R A C T

Ke y w or d s
Indian mustard,
Alternaria
brassicicola,
Management,
Nutrients and
Fungicides
Article Info
$\begin{aligned} & \text { Accepted: } \\ & \text { 22 June } 2020 \\ & \text { Available Online: } \\ & \text { 10 July } 2020\end{aligned}$

Alternaria blight of mustard caused by Alternaria brassicicola is one of the most wide spread and destructive disease of rapeseed-mustard. To manage the disease - nutrients and fungicides were tested against Alternaria brassicicola, causing Alternaria blight of mustard. Efficacy of five nutrients were tested through foliar spray. Out of five, potassium proved to be most effective against Alternaria blight followed by copper in reducing per cent disease intensity. Efficacy of five fungicides viz. (azoxystrobin+hexaconazole), carbendazim + mancozeb, mancozeb, propineb and copper oxychloride were tested in in vitro conditions by poisoned food technique showed that (azoxystrobin + hexaconazole) was found most effective in inhibiting mycelial growth of Alternaria brassicicola at 200 and 300 ppm concentration followed by mancozeb. Foliar application of (azoxystrobin + hexaconazole) $(0.1 \%)$ was found effective in reducing disease intensity.

\section{Introduction}

Oilseed crops play an important role in agricultural economy of India. Oilseed Brassicas often called rapeseed-mustard placed in Brassicaceae family. Oilseed Brassicas are the third most important oil seed crop in terms of acreage and production after soybean and palm in the world and occupy second position after groundnut in India (Kumar and Chopra, 2014). Among rapeseedmustard, Indian mustard is one of the most important which contribute about 85 per cent of total rapeseed-mustard produced in India (Kumar and Chauhan, 2005). Major Indian mustard growing states are Rajasthan, Madhya Pradesh, UP, Haryana, Punjab and Gujarat. It is also grown under some non- 
traditional areas of South India including Karnataka, Tamilnadu and Andrapradesh. Indian contribution in global rapeseedmustard production is 6.33 million tonnes with an area of 6.412 million hectares (Anonymous, 2017-18). In Rajasthan, rapeseed-mustard occupies a prime position amongst all the oilseed crops grown in state. Rajasthan ranks first both in area and production of rapeseed-mustard in the country. In Rajasthan, the mustard crop is mostly cultivated in Alwar, Bharatpur, Jaipur, Dholpur, Sawaimadhopur, Sriganganagar, Jhunjhunu and Sikar districts. It occupies 2.379 million hectares area with 3.588 million tonnes production (Anonymous, 2018-19).

The symptoms of Alternaria blight disease appears on leaves and stems of seedlings and adult plants and also in siliquae during the ripening stage. Dark spots on the leaves and siliquae reduce the photosynthetic capacity and induce immature ripening, which causes reduced amount of quality seed production in both vegetable and oleiferous Brassicas (Kumar et al., 2014). Chadar et al. (2016) recorded 23.9-62.0 per cent disease intensity of leaf blight of mustard which occurred widely in Jhansi region of India.

\section{Materials and Methods}

Effect of nutrients on disease development The experiment was carried out in earthen pots $(30 \mathrm{~cm}$ dia.) with highly susceptible variety, Varuna (T-59) at SKN College of Agriculture, Jobner (Jaipur). All the experimental pots fertilized with the recommended dose of fertilizers. Five different treatments mentioned below including untreated control were applied in the form of chemical fertilizers. Nutrients were sprayed on plants at 40 days after sowing (DAS) while inoculation was done at 50 days after sowing. Per cent disease intensity was recorded 90 DAS.

\section{Efficacy of fungicides (In vitro)}

Efficacy of five systemic and non-systemic fungicides against growth of Alternaria brassicicola was tested by Poisoned Food Technique. Three different concentrations viz., 100, 200 and $300 \mathrm{ppm}$ of each fungicide were tested. Weighted quantity of each fungicide was added in autoclaved PDA medium and mixed thoroughly. The poisoned medium was poured in sterilized Petri plates and allowed to solidify. Each plate was inoculated with $5 \mathrm{~mm}$ disc of fungal culture and incubated at $25 \pm 1^{0} \mathrm{C}$ for seven days. The linear growth of the test fungus was recorded at $7^{\text {th }}$ day of incubation. A check was also maintained where fungicide was not added in the medium. Per cent inhibition of mycelial growth was calculated according to Vincent's formula (1947).

Per cent inhibition $=\quad \begin{gathered}\text { C-T } \\ -------- \\ \text { x } 100\end{gathered}$

Where, $\mathrm{C}=$ Diameter of the colony in control (Average of both diagonals)

$\mathrm{T}=$ Diameter of the colony in treatments (Average of both diagonals)

\section{Efficacy of fungicides (In vivo)}

Efficacy of fungicides against Alternaria blight of mustard was tested under cage house conditions. Mustard plants were raised in cage house of Department of Plant Pathology, S.K.N. College of Agriculture, Jobner. The experiment was carried out in earthen pots (30 $\mathrm{cm}$ dia.) with cultivar Varuna (T-59). Five fungicides were tested by foliar application at the time of disease initiation. Plants were inoculated by spraying with aqueous suspension of Alternaria brassicicola $\left(2 \times 10^{3}\right.$ spores $/ \mathrm{ml}$ ) at 40 DAS. PDI was recorded at 90 DAS. Per cent disease intensity (PDI) and per cent disease control (PDC) were calculated 
using following formula suggested by Conn et al. (1990).

Sum of rating of the leaves infected

$\mathrm{PDI}=\longrightarrow$ X 100

Number of leaves $\mathrm{x}$ maximum disease rating

PDI in check - PDI in treatment

$\mathrm{PDC}=$

PDI in check

\section{Results and Discussion}

\section{Effect of nutrients on blight}

Foliar application of nutrients gave promising results (Table 1) in minimizing per cent disease intensity at 90 days after sowing (DAS) and all were significantly superior over control. At 90 days after sowing (DAS), minimum disease intensity was observed with $\mathrm{K}(40.75 \%)$ followed by $\mathrm{Cu}(43.75 \%), \mathrm{Zn}$ (48.25\%), B (53.28\%), Fe (52.51\%) over control $(57.51 \%)$. Foliar application of nutrients were found effective in minimizing disease intensity. Among these, $\mathrm{K}$ and $\mathrm{Cu}$ were found highly effective in reducing disease severity which is also in accordance with the findings of Kumar et al. (2014) who reported the positive effect of micronutrients in reducing disease caused by Alternaria brassicicola.

\section{Effect of fungicides on blight}

Efficacy of five fungicides each at three concentrations viz., 100, 200 and 300 ppm were tested in vitro by Poisoned Food Technique against Alternaria brassicicola. The data recorded on per cent growth inhibition are presented in (Table2). Among five fungicides, azoxystrobin + hexaconazole was found most effective in inhibiting mycelial growth (94.00, 100 and 100\%) of Alternaria brassicicola at 100, 200 and 300 ppm, respectively followed by mancozeb (72.02, 72.77 and 89.80\%) over control. Fungicides, carbendazim + mancozeb (60.16, 62.88 and $72.22 \%$ ), copper oxychloride $(56.76,61.11$ and $66.67 \%)$ and propineb $(35.35,44.44$ and $50.00 \%)$ were found least effective in inhibiting mycelial growth over control.

Table.1 Effect of different nutrients on Alternaria leaf blight of mustard (foliar application)

\begin{tabular}{|l|l|c|c|c|}
\hline S.No & Nutrients & Concentration (\%) & Per cent disease intensity & Percent disease control \\
\hline $\mathbf{1}$ & Copper sulphate & 0.5 & 43.75 & 25.23 \\
\hline $\mathbf{2}$ & & & $(41.41)$ & 17.54 \\
\hline & Zinc sulphate & 0.5 & 48.25 & 8.94 \\
\hline $\mathbf{3}$ & Borax & & $(44.00)$ & 10.25 \\
\hline & & 0.5 & 53.28 & \\
\hline $\mathbf{4}$ & Ferrous sulphate & 0.5 & $(46.88)$ & 30.35 \\
\hline \multirow{2}{*}{} & & & 52.51 & 0.00 \\
\hline & Potasiumsulphate & 0.5 & $(46.44)$ & \\
\hline $\mathbf{6}$ & & & 40.75 & \\
\hline & Control & - & $57.67)$ & \\
\hline & & & $(49.90)$ & \\
\hline & SEm \pm & & 0.89 & \\
\hline
\end{tabular}

*Average of four replications. Figures given in parentheses are angular transformed values. 
Table.2: Efficacy of fungicides against mycelial growth of Alternaria brassicicola by Poisoned Food Technique on $7^{\text {th }}$ day of incubation at $25 \pm 1{ }^{0} \mathrm{C}$

\begin{tabular}{|c|c|c|c|c|c|}
\hline \multirow[t]{2}{*}{ S.No. } & \multirow[t]{2}{*}{ Fungicide } & \multicolumn{3}{|c|}{ Per cent growth inhibition at various concentration* } & \multirow[t]{2}{*}{ Mean } \\
\hline & & $100 \mathrm{ppm}$ & $200 \mathrm{ppm}$ & 300 ppm & \\
\hline \multirow[t]{2}{*}{1} & Mancozeb & 72.02 & 72.77 & 89.80 & 78.20 \\
\hline & & $(58.06)$ & $(58.55)$ & (71.37) & $(62.16)$ \\
\hline \multirow[t]{2}{*}{2} & Propineb & 35.35 & 44.44 & 50.00 & 43.26 \\
\hline & & $(36.48)$ & $(41.81)$ & $(45.00)$ & $(41.13)$ \\
\hline \multirow[t]{2}{*}{3} & Copper oxychloride & 56.76 & 61.11 & 66.67 & 61.51 \\
\hline & & $(48.89)$ & $(51.42)$ & $(54.74)$ & $(51.66)$ \\
\hline \multirow[t]{2}{*}{4} & Carbendazim+ Mancozeb & 60.16 & 62.88 & 72.22 & 65.09 \\
\hline & & $(50.86)$ & $(52.46)$ & $(58.19)$ & $(53.78)$ \\
\hline \multirow[t]{2}{*}{5} & Azoxystrobin+Hexaconazole & 94.00 & 100.00 & 100.00 & 98.00 \\
\hline & & $(75.82)$ & $(90.00)$ & $(90.00)$ & (81.87) \\
\hline \multirow[t]{8}{*}{6} & Control & 0.00 & 0.00 & 0.00 & 0.00 \\
\hline & & $(0.00)$ & $(0.00)$ & $(0.00)$ & $(0.00)$ \\
\hline & Mean & 53.05 & 56.87 & 63.12 & \\
\hline & & $(46.75)$ & $(48.95)$ & $(52.60)$ & \\
\hline & & $\mathrm{SEm} \pm$ & \multicolumn{2}{|c|}{$\mathrm{CD}(\mathrm{p}=0.05)$} & \\
\hline & Fungicide (F) & $2.00^{-}$ & 5.54 & & \\
\hline & Concentration (C) & 1.61 & 4.44 & & \\
\hline & $\mathrm{F} \times \mathrm{C}$ & 2.78 & 7.70 & & \\
\hline
\end{tabular}

*Average of four replications. Figures given in parentheses are angular transformed values.

Table.3 Efficacy of fungicides against Alternaria blight of mustard (in vivo)

\begin{tabular}{|l|l|c|c|c|}
\hline S. No & Fungicide & Concentration (\%) & $\begin{array}{c}\text { Per cent disease } \\
\text { intensity }\end{array}$ & $\begin{array}{c}\text { Percent } \\
\text { disease } \\
\text { control }\end{array}$ \\
\hline $\mathbf{1}$ & Mancozeb & 0.25 & 12.40 & 78.81 \\
\hline $\mathbf{2}$ & Copper oxychloride & 0.1 & $(20.62)$ & \\
\hline $\mathbf{3}$ & Propineb & 0.25 & $(24.50$ & 70.09 \\
\hline $\mathbf{4}$ & Carbendazim+ Mancozeb & 0.2 & 23.00 & 60.69 \\
\hline & & & $(28.66)$ & \\
\hline $\mathbf{5}$ & Azoxystrobin+ Hexaconazol & 0.1 & $(22.60$ & 74.71 \\
\hline & & & 9.00 & 84.62 \\
\hline $\mathbf{6}$ & Control & & $(17.46)$ & \\
\hline & & & 58.51 & - \\
\hline & SEm \pm & & $(49.90)$ & \\
\hline & CD $(\mathrm{p}=0.05)$ & & 4.43 & \\
\hline
\end{tabular}

*Average of five replications, PDI= 90 DAS

Figures given in parentheses are angular transformed values 
Data presented in (Table 3) shows that all fungicides under study were significantly superior over control. Azoxystrobin + hexaconazole was found most effective in reducing per cent disease intensity $(84.62 \%)$ followed by mancozeb (78.81\%), carbendazim + mancozeb $(74.71 \%)$ and copper oxychloride $(70.09 \%)$. Propineb was least effective in reducing per cent disease intensity (60.69\%).All the fungicides were found effective in reducing the per cent disease intensity over control. All the fungicides were found significantly superior over check in controlling the disease. Our results are in accordance with the findings of Kumar et al. (2018) foliar spray with mancozeb $(0.2 \%)$ at 45 DAS followed by hexaconazole $(0.05 \%)$ at 60 DAS was found most effective in controlling Alternaria leaf blight severity up to 78.0 per cent and Alternaria pod blight severity up to 56.5 per cent and increased seed yield upto 29.9 per cent as compared to untreated control. Singh and Singh (2007) have also reported that foliar spray of mancozeb was found effective in reducing the disease severity followed by Bavistin and Blitox-50.

\section{References}

Anonymous. 2017-18. Directorate of Economics and Statistics, Deptt. of Agriculture and Cooperation, Delhi : pp 10-12.

Anonymous. 2018-19. Rajasthan agricultural statistics. At a glance statistical cell, Commissionerate of Agriculture, Rajasthan, Jaipur, pp1.

Chadar, L. K., Singh R. P., Singh. R. K.,
Yadav, R. R., Mishra, M. K., Pratap. N. and Vishnoi, R. K. 2016. Studies on Alternaria blight of rapeseed-mustard (Brassica junceaL.) caused by Alternaria brassicae (Berk.) Sacc. and its integrated management. Plant Archives, 16(2): 897-901.

Conn, K.L., Tiwari, J.P. and Awasthi, R.P. 1990. A disease assessment key for Alternaria black spot in rapeseed and mustard. Canadian Plant Disease Survey, 70: 19-22.

Kumar, A., and Chauhan, J.S. 2005. Strategies and future thrust areas of rape seed mustard research in India. Indian Journal Agriculture Science, 75: 621635.

Kumar., R.A. and Rathi, A.S. 2018. Management of Alternaria blight in Indian mustard through fungicides under field conditions. International Journal of Chemical Studies, 6 (2): 2042-2044.

Kumar, V., and Chopra, A.K. 2014. Fertiirrigational response of hybrid cultivar of Indian mustard (Brassica junceaL.) to distillery effluent in two seasons. Analitical Chemical Letters, 4 (3): 190206.

Singh R., and Singh, V.K. 2007. Evaluation of fungicides against Alternaria Blight of Brassica campestris var. Yellow Sarson. Annals of Plant Protection Sciences. ; 15 (1) : 235-81.

Vincent, J.M. 1947. The esters of 4-hydroxyl benzoic acid and related compound. Methods for the study of their fungistatic properties. Journal Science Indian, 16: 749-755.

\section{How to cite this article:}

Sumitra, S. Meena, S. Choudhary, P. Yadav, S. Godika and Ghasolia, R. P. 2020. Management of Alternaria Blight Disease of Mustard through Nutrients and Fungicides. Int.J.Curr.Microbiol.App.Sci. 9(07): 2665-2669. doi: https://doi.org/10.20546/ijcmas.2020.907.313 